CORRIGENDUM

\title{
Novel permissive murine immunocompetent orthotopic colon carcinoma model for comparison of the antitumoral and safety profiles of three Adv-TKs
}

\author{
C Chen, H Fang, Z Han, F Ye, T Ji, D Gong, F Li, J Zhou, D Ma and Q Gao
}

Gene Therapy (2015) 22, 286; doi:10.1038/gt.2014.118

Correction to: Gene Therapy (2014) 21, 975-983; doi:10.1038/ gt.2014.79; published online 4 September 2014

Since the publication of this article the authors have noticed an error with regard to Figures $2 \mathrm{e}$ and $\mathrm{g}$. The correct Figure 2 is reproduced here.

a

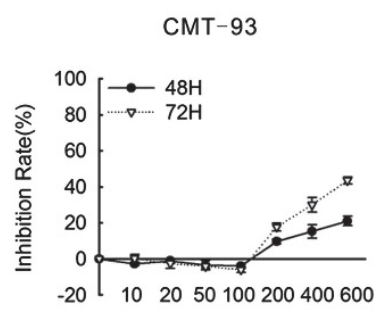

e

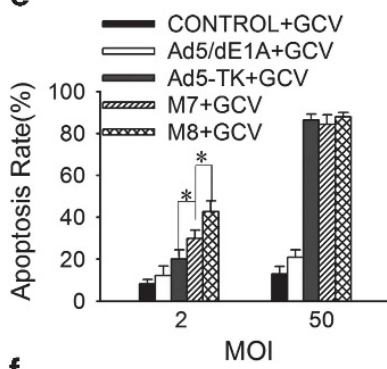

f

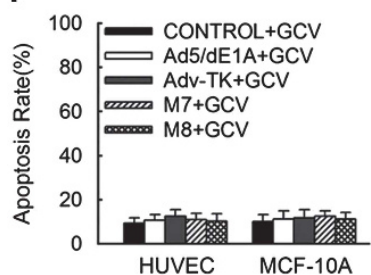

b

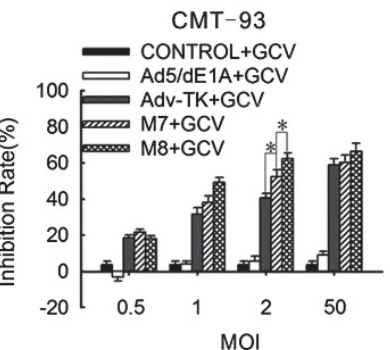

g

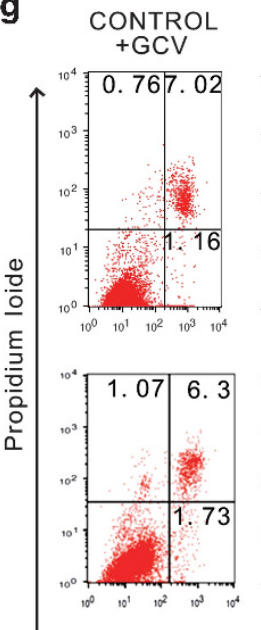

c
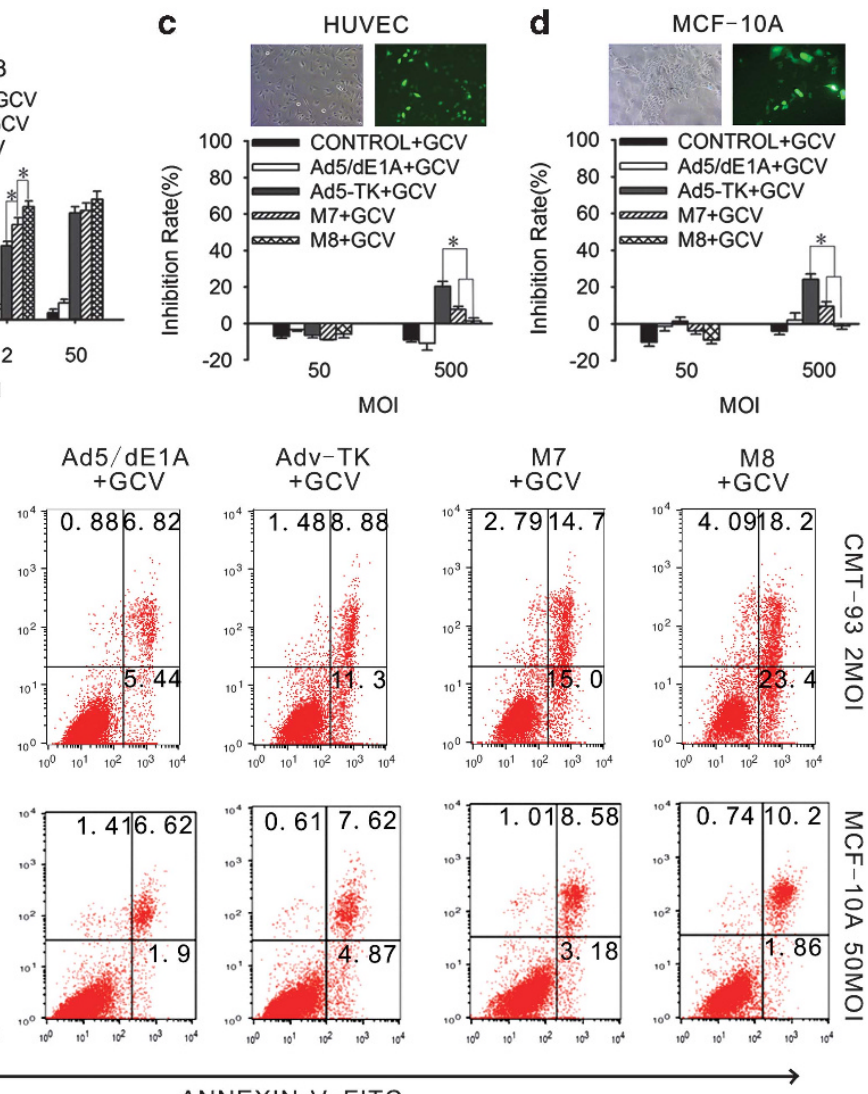

Figure 2. Effects of Adv-TK, M7 and M8 on CMT-93 cells and non-cancerous cells in vitro. (a) CMT-93 cells were administered with increasing concentrations of GCV $\left(0-600 \mu \mathrm{g} \mathrm{ml}^{-1}\right)$. Cell proliferation was assessed by MTT assay after $72 \mathrm{~h}$. (b) CMT-93 cells were infected with various viral mutants at various MOI in the presence of $100 \mu \mathrm{g} \mathrm{ml}^{-1}$ of GCV. Cell proliferation was assessed by MTT assay $72 \mathrm{~h}$ after infection. (c-d) Noncancer cells, HUVEC and MCF-10A, were infected with various viral mutants at a MOI of 50 or 500 in the presence of $100 \mu \mathrm{ml}^{-1}$ of GCV; $^{-1}$ transfect efficacy was determined $24 \mathrm{~h}$ after transfection of $500 \mathrm{MOI}$ Adv-GFP, and cell proliferation was assessed by MTT assay $72 \mathrm{~h}$ after infection. (e) CMT-93 cells were infected with various viral mutants at a MOI of 2 or 50 in the presence of $100 \mu \mathrm{g} \mathrm{ml} \mathrm{m}^{-1}$ of GCV, apoptosis was assessed by flow cytometry $72 \mathrm{~h}$ after infection. (f) Non-cancer cells, HUVEC and MCF-10A, were infected with various viral mutants at a MOI of 50, apoptosis was assessed by flow cytometry $72 \mathrm{~h}$ after infection. (g) Representative flow cytometric analysis of the effects of Adv-TK, M7 and M8 administered in combination with $100 \mu \mathrm{g} \mathrm{ml}^{-1} \mathrm{GCV}$ in CMT-93 and MCF-10A cells. All the results were presented as the means of values obtained in three independent experiments. 